\section{SURGEONS TWOE AND A BARBER}

By Donald McDonald. Pp. xix +295 , with 2 I illustrations. London: William Heinemann. I950. $42 \mathrm{~s}$.

This book has been awaited with particular pleasure by many members of the Indian Medical Service, for few are lucky enough to possess a copy of Dirom Grey Crawford's larger history and this, in any case, takes the story no further than I9r4. It should, however, appeal to many beside those who served in India.

As Macaulay said of Hallam's ' Constitutional History,' this book is a map rather than a landscape, but this is inherent in any attempt to cover a period of nearly 350 years in 293 pages.

The Indian Medical Service from its humble beginnings attracted men of widely differing attainments. Many were accomplished clinicians who achieved fame in medicine, many were original thinkers who advanced medicine by their research, many were great administrators who found that the whole of India was their arena, many were brave and fine soldiers inspired by that peculiar sense of duty and responsibility which defies analysis but which is the soldiers own. The majority were more simple men who acquired a sense of loyalty, of affection and of trust towards India which made their life and their work full and sufficient. All these are in this book and others whose erratic behaviour causes delight and astonishment in this age of regulations.. It is a pity that our respect for the living (probably influenced to some small extent by the laws relating to libel) precludes mention of our more modern eccentrics who displayed at least as sturdy an independence as their predecessors.

It would have been easier for those unacquainted with India if more maps had been provided for their guidance, and these might well have replaced some of the large number of photographs scattered throughout the book.

Once the dust cover has been lost one will have to rely on the official description given in the Foreword, the portrait of Sir William Rice Edwards on page 195 and a magnifying glass for a knowledge of what the I.M.S. crest looks like. These, however, are small criticisms of a book which is a delight to read and which portrays so faithfully that piece of history which was the Indian Medical Service.

D.R.H.

\section{LUMBAR PUNCTURE AND SPINAL ANALGESIA}

By R. R. Macintosh, M.A., D.M., F.R.C.S., D.A. Pp. vii + 149, with III illustrations. Edinburgh: E. and S. Livingstone. 195I. 21 s.

It is rather surprising to receive a new publication on spinal analgesia when there is a tendency by many authorities to regard its use as unjustifiable since the introduction of curarizing drugs and, further, the literature on the subject is already profuse. However, in so far as the book intends to give a clear description of the technique of lumbar puncture and the principles of spinal analgesia, it fulfils its purpose well.

The book begins with a brief historical survey of spinal analgesia followed by an excellent and wellillustrated description of the anatomy of the spinal canal. The later chapters are devoted to methods of sterilization, the safest being autoclaving of all instruments and solutions to be used, and technique of puncture in which the use of an introducer and approach slightly lateral to the midline are advocated. The distribution of analgesic solutions introduced into the subarachnoid space is also described and although most anaesthetists will require a fuller account of different techniques, the principles involved are clearly displayed. Prof. Macintosh considers that the $I: I, 500$ ' light' nupercaine solution should be regarded as isobaric and the height of analgesia controlled by the volume of solution introduced rather than by posture. The middle section of the book consists of a series of illustrations, excellent in themselves, but which would have been better arranged in the appropriate context rather than aggregated, making a somewhat. disjointed chapter.

This book, although limited from the anaesthetist's point of view, will prove a good introduction to the subject for the beginner.

\section{BRITISH RHEUMATIC ASSOCIATION:}

\section{Third Annual Report, 1949-1950}

\section{Pp. 36. Gratis.}

The British Rheumatic Association was formed just over three years ago with the object of alleviating 'the present widespread human suffering from the disease of rheumatism in all its forms; to assist and promote the rehabilitation of those afflicted by it, and thereby to eradicate the economic loss to the community in terms of manpower and productive effort occasioned by this disease.' Membership of the association is open to all on payment of a small annual fee.

The third annual report of the association gives details of the progress made since its inception, and in the pages which follow many of the problems associated with the rheumatic diseases are discussed. The future aims of the association are then outlined, including the provision of accommodation for the disabled, widening of facilities for home treatment, the promotion of an educational campaign and investigation into the problems of employment under medical supervision.

The association publishes its own quarterly journal, the B.R.A. Review, which is intended primarily for the lay reader but which also contains articles of medical interest and reports the various activities of the association.

Although much of the work of the association is covered by the present day hospital almoner service, sufferers to whom these facilities are not available might well derive benefit from membership. 